\title{
ANIMAL ABUSE DILIHAT DARI SUDUT PANDANG
}

FILSAFAT MANUSIA

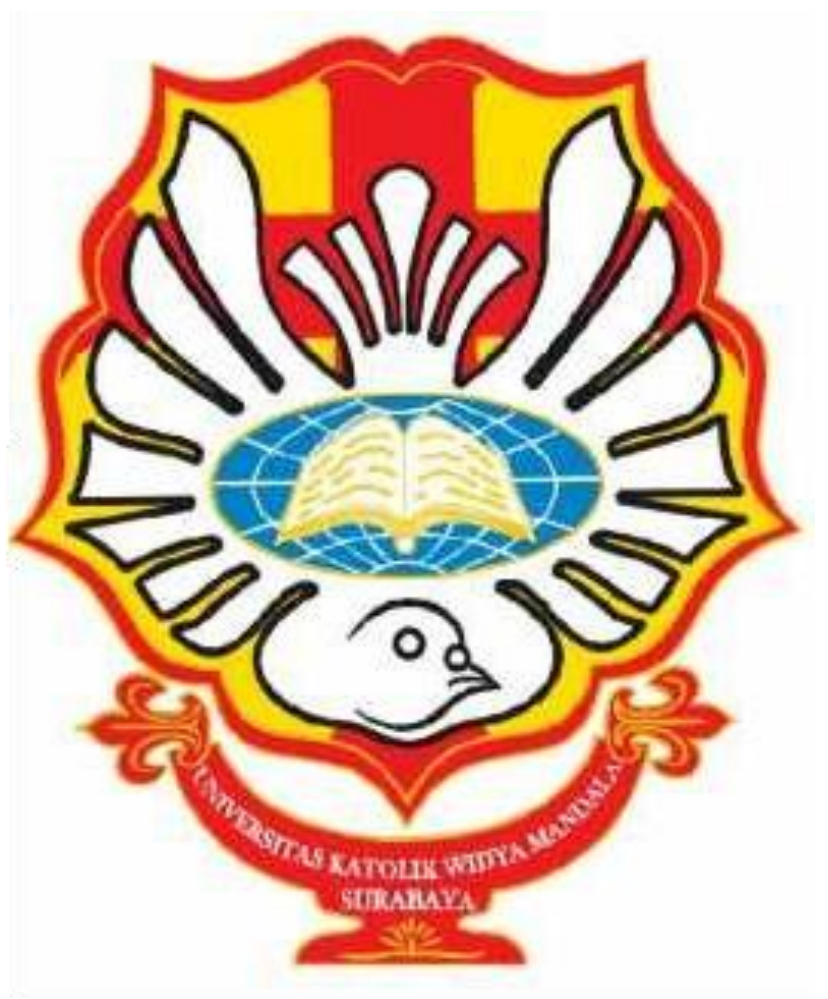

Ditulis oleh:

Arif Wahyu Utomo (41417003)

FAKULTAS TEKNIK

\section{PROGRAM STUDI TEKNIK INDUSTRI}

UNIVERSITAS KATOLIK WIDYA MANDALA SURABAYA

KAMPUS MADIUN

2019 


\begin{abstract}
Abstrak
Kejahatan terhadap hewan (Animal Abuse) adalah hal yang sangat sering terjadi, tidak hanya di negara kita saja tetapi kejahatan pada hewan juga terjadi di berbagai Negara, banyak kasus yang terjadi dari hanya penelantaran hewan sampai penyiksaan hewan adalah hal yang biasa terjadi. Pelakunya tidak lain dan tidak bukan adalah manusia, ya kita tau manusia adalah mahluk yang diistimewakan mereka dianugrahi kemampuan berpikir tetapi banyak dari mereka tidak bisa menggunakan kemampuan berpikir dengan baik. Maka dari itu filsafat manusia hadir untuk membantu manusia untuk merubah cara berpikir mereka menjadi berpikir yang baik yang tidak hanya memikirkan diri mereka sendiri tetapi juga memikirkan kesejahteraan hidup mahluk hidup lain. Dimulai dengan filsafat sebagai proses berpikir, mengenal perbedaan manusia dengan hewan, mengenal manusia menurut para filsuf. Maka dengan itu semua diharapkan manusia lebih peka terhadap kelangsungan hidup mahluk hidup lain
\end{abstract}

Keyword: Manusia, Animal Abuse, Sikap manusia terhadap hewan, Pola Pikir, Filsafat Manusia

\title{
Pendahuluan
}

Tuhan menciptakan alam semesta beserta seluruh isinya dengan keistimewaan dan keindahannya masing-masing. Dari seluruh ciptaan Tuhan yang ada di alam semesta ini, manusia adalah salah satu ciptaan Tuhan yang memiliki keistimewaan secara lebih dari pada makhluk-makhluk lainnya. Manusia diciptakan dengan akal yang mampu menyerap segala bentuk pengetahuan melalui panca indera yang mereka olah dengan pikiran dan nalar mereka masing-masing. Tak hanya diberikan keistimewaan yang lebih, namun manusia bukanlah makhluk yang sempurna, manusia juga perlu berinteraksi dengan makhluk hidup lainnya seperti sesama manusia lain atau bahkan dengan hewan dan tumbuhan. 
Kita sering menjumpai hubungan baik antara manusia dan hewan di sekitar kita. Tetapi tidak semua manusia dan hewan memiliki hubungan yang baik. Pastinya disekitar lingkungan kita berada juga terdapat manusia-manusia yang membenci keberadaan hewan tersebut, dan sifat benci mereka ke hewan dapat menyebabkan tindakan kekerasan pada hewan yang berakibat cacat pada hewan, bahkan ada yang sampai mati.

Selain rasa benci, terdapat juga manusia yang tidak membenci tetapi tidak juga menyukai tetapi memanfaatkan hewan untuk keuntungan pribadinya. Dalam pemanfaatan hewan, manusia itu terkadang memperlakukan hewan tersebut dengan cara yang tidak baik, seperti memaksa dan mengancam hewan tersebut dengan cara yang membuat hewan tersebut tersiksa.

Berikut adalah beberapa contoh kekerasan pada hewan yang tentu saja kami dapatkan informasinya dari situs berita dan beberapa situs pencinta hewan:

1. Pemasungan Gajah selama 50 tahun di India

Raju, nama seekor gajah yang menghabiskan 50 tahun hidupnya dengan dipasung oleh orang yang menangkapnya. Setelah 50 tahun dipasung, ia akhirnya bebas dengan pertolongan dari Wildlife SOS (badan amal yang berpusat di London Utara).

Dengan waktu 24 jam terpasung selama 50 tahun, Raju hidup hanya dari belas kasihan orang yang melewatinya. Penderitaan Raju sangatlah berat, orang yang menangkap Raju memasungnya dengan cara memberi rantai paku yang mampu merobek daging kaki Raju ketika Raju bergerak. Raju pun hanya bisa duduk sambil menahan sakit di kakinya.

Namun setelah 50 tahun masa penderitaan Raju, Raju pun berhasil diselamatkan, dan ketika penyelamatan itu berlangsung, Raju meneteskan air mata. lalu Raju dibawa dengan truk ke area Konservasi dan Pusat Perawatan Gajah di Mathura. Wildlife SOS membuat kampanye memberikan sumbanga untuk kehidupan baru Raju. (sumber: www.merdeka.com) 


\section{Penyiksaan Hewan Sirkus}

Hewan-hewan yang mampu menghibur kita di tempat-tempat hiburan rupanya tidak selalu mendapat perlakuan yang baik dari pihak penyelanggara. Banyak hewan-hewan tersebut disiksa agar mampu melakukan atraksi untuk menghibur para penontonnya.

Seperti Wildlife Animal Sanctuary baru saja menyelamatkan puluhan ekor singa yang dipekerjakan sebagai anggota sirkus keliling. Singa-singa tersebut dipekerjakan secara paksa dalam sirkus keliling di Peru. Terdapat salah satu singa yang kehilangan sebelah matanya karena penyiksaan untuk melakukan sirkus tersebut.

Selain sirkus singa di Peru, ternyata di Indonesia juga terdapat hal serupa. Namun di Indonesia hewan yang secara langsung disiksa untuk ajang sirkus adalah lumba-lumba. Pertunjukkan sirkus lumba-lumba keliling menyebabkan perlakuan penyelenggara kepada lumba-lumba menjadi semena-semena. Seperti halnya kulit lumba-lumba yang cepat keirng karena terpapar udara hanya diberi pelembab, bahkan jika tidak ada pelembab maka diberikan mentega. Setelahnya lumba-lumba dibawa dengan truk dan dimasukkan ke dalam peti sempit dan gelap, hal itu mampu membuat lumba-lumba menjadi stres.

Tak hanya perlakuan diluar pertunjukkan, pada saat pertunjukkan pun kolam yang digunakan untuk atraksi lumba-lumba tersebut diisi oleh air laut buatan. Penyelenggara membuat air asin ini dengan mencampurkan air ledeng dengan berton-ton garam. Senyawa pembunuh kuman bernama klorin dicampurkan ke dalam air kolam. Klorin yang bersifat korosif dipastikan merusak organ mata yang sensitif dan lumba-lumba pun menjadi rabun. (sumber: m.tempo.co)

Perlakuan hewan untuk pertunjukkkan hiburan juga sama dengan penyiksaan terhadap hewan, dan itu termasuk kegiatan yang hanya mementingkan keuntungan tersendiri bagi manusia yang melakukannya. 


\section{Keisengan bocah-bocah menyiksa kucing}

Kekerasan hewan yang disebabkan oleh keusilan manusia untuk mengganggu keberadaan hewan tersebut adalah kasus yang tak lama beredar di media sosial yaitu video 3 bocah di Indonesia yang menganiaya kucing dengan sengaja. Dalam video yang terunggah, bocah-bocah itu membakar dagu kucing hingga kucing tersebut meronta kesakitan. Dan tidak diketahui apa maksud tindakan mereka tersebut, namun yang terlihat 3 bocah itu merasa senang ketika menyiksa kucing tersebut. (sumber: http://style.tribunnews.com/)

\section{Teori}

Dalam kasus ini kita akan membahas tentang kejahatan manusia pada hewan (Animal Abuse) sebagai manusia yang memiliki nalar kita seharusnya sadar akan perbuatan baik dan buruk, hewan memiliki peranan yang penting bagi kehidupan manusia karena hewan bisa menjadi teman dan sumber pangan bagi kita. Tetapi mengapa bebrapa dari kita sering memerlakukan hewan dengan semenamena seperti menyiksa, membunuh, mengekploitasi dengan cara menjadikan mereka sebagai hewan sirkus yang dimana hasil dari pertunjukan itu untuk keuntungan si manusia.

Dari sudut pandang filsafat sebagai proses berpikir

Manusia adalah mahluk yang senantiasa berpikir, dengan kemampuan berpikir inilah, pada awalnya manusia merasa heran dengan segala sesuatu yang ada dan terjadi di alam semesta. Hingga akhirnya dengan kemampuan berpikir inilah manusia mendapat suatu jawaban yang logis. Proses berfilsafat adalah proses berpikir tetapi tidak semua proses berfikir adalah berfilsafat

Filsafat membantu manusia untuk mencari kebenaran dari segala fenomena yang ada, memberikan pengertian tentang cara hidup, pandangan hidup, dan pandangan dunia, memberikan ajaran tentang moral dan etika yang berguna dalam kehidupan memahami diri sendiri dan dunia, mengembangkan kemampuan dalam 
menalar, dan memberikan bekal untuk memperhatikan pendangan diri sendiri dan orang lain dengan kritis. Lebih jauh dari itu filsafat memberikan pandangan yang luas sehingga manusia dapat membendung egoism dan ego-sentrisme, membebaskan manusia dari belenggu cara berpikir yang sempit, memberikan landasan historis-filosofis bagi setiap kajian disiplin ilmu yang ditekuni, memberikan nilai dan orientasi yang jelas bagi setiap disiplin ilmu.

Kegiatan keilmuan adalah suatu proses kegiatan berpikir. Kegiatan berpikir tersebut bertujuan untuk mendapatkan pengetahuan yang bersifat umum dalam bentuk teori, hokum-hukum, kaidah-kaidah dan asas dari berbagai permasalahan. Secara garis besar ilmu dikelompokkan dalam ilmu alam dan ilmu social. Ilmu alam sasarannya adalah alam semesta. Ilmu pengetahuan social bidang kajiannya adalah prilaku manusia. Ilmu pengetahuan alam masih dikelompokkan dala ilmu fisik dengan bidang kajian benda-benda mati, dan biologi yang bidang sasarannya adalah mahluk hidup. (Dewantara, 2019).

Dengan berfilsafat manusia bisa mencari tahu dan mengerti hal yang baik dan buruk yang mana harus dilakukan dan mana yang tidak boleh dilakukan. Kejahatan hewan adalah salah satu contoh tindakan yang buruk yang seharusnya tidak dilakukan. Memang manusia sangat diistemewakan mereka diperbolehkan menguasai alam semesta itu tetapi sebagai manusia yang memiliki nalar seharusnya kita tahu kalau tindakan penyiksaan terhadap hewan itu tidak boleh karena banyak hewan-hewan yang punah dikarenakan penembakan liar dan pembakaran hutan kalau salah satu hewan punah pasti akan merusak ekosistem yang ada di lingkungan tersebut

Manusia menurut para filsuf

Aristoteles membedakan manusia dan hewan berdasarkan kepemilikan bahasa. Manusia memiliki bahasa yang memungkinkannya berkomunikasi dalam polis dan membedakan baik-buruk. Bagi Descartes, adalah suatu hal yang jelas bahwa hanya manusia yang memiliki akal budi atau rasionalitas. Hanya 
manusia yang mampu meragukan dirinya. Tindakan meragukan itulah yang membuat dirinya menjadi manusiawi. (Dewantara, 2019).

Pada akhirnya, pandangan Descartes sendiri sama seperti Aristoteles. Ia memandang bahwa ada perbedaan signifikan yang amat besar yang membedakan manusia dan hewan. Manusia memiliki karakteristik spesial yang tak dimiliki oleh hewan, seperti bahasa dan akal budi.

Dari perbedaan antara manusia dan hewan diatas ada salah satu filsuf yang menyatakan manusia dan hewan juga memiliki sebuah persamaan yaitu keduanya sama-sama bisa menderita filsuf itu adalah Jeremy Bentham. Bentham sendiri adalah salah satu filsuf yang menolak antroposentrisme dengan argumen tersohornya mengenai kemampuan hewan untuk mengalami rasa sakit (ability to suffer). Raja, Unies Ananda (2018, 25 Januari). Sejarah Singkat Diskursus mengenai Hewan dalam Filsafat Barat. Diakses pada 30 November 2019, dari http://www.balairungpress.com/2018/01/sejarah-singkat-diskursus-mengenaihewan-dalam-filsafat-barat/

\section{Argumentasi}

Ditinjau dari pendapat beberapa filsuf tentang perbedaan manusia dengan hewan, dapat dikatakan memang manusia memiliki derajat yang lebih tinggi di bandingkan hewan dan tumbuhan di alam semesta ini, manusia diciptakan dengan akal budi yang dapat membedakan hal buruk dan yang baik dapat berbicara dengan bahasa yang dimengerti. Meskipun hewan tidak bernalar dan tidak berbahasa seperti manusia, harusnya yang dipertanyaannya bukan, bisakah mereka bernalar atau tidak dapat berbicara? tetapi, dapatkah mereka menderita? Menurut saya mereka sangat bisa menderita, disaat hewan lain hidup berkelompok di alam liar melakukan aktivitas yang mereka ingin lakukan. Ada seekor kera yang berada kota yang sedang dipaksa untuk dilatih agar patuh dengan perintah dan melakukan atraksi yang sebenarnya tidak ingin mereka lakukan terkadang mereka dilatih dengan dipukul mereka cepat memahami perintah dan jika mereka melakukan kesalahan mereka juga dipukul, di beri makanan yang hanya ala kadarnya. 
Dipaksa untuk beraktraksi yang nanti uang hasil dari atraksi yang mereka lakukan di gunakan sepenuhnya oleh sang manusia. Sekarang dimana letak akal budi manusia yang menjadi pelaku Animal Abuse ini apakah mereka tidak sadar akan penderitaan hewan-hewan yang mereka ekploitasi hanya untuk menghasilkan uang yang mereka inginkan atau sebenarnya mereka sadar tetapi tidak peduli akan hal tersebut.

Sebenarnya di Negara ini apakah tidak ada hukum yang mengatur itu semua? Jawabanya adalah ada, Indonesia sudah memiliki hukum tersebut, tetapi mengapa masih banyak terjadi kejahatan pada hewan? Itu karena kurangnya pemahaman para warga kita akan kepedulian terhadap hewan,mereka masih masih menganggap kalau hewan itu cuma sekedar mahluk hidup biasa kalau dibunuh, di telantarkan atau bahkan di ekploitasi untuk dijadikan hewan sirkus itu biasa

Itulah mengapa pentingnya UU yang mengatur perihal kesejahteraan satwa di Indonesia memiliki UU yang mengatur itu semua terdapat pada Undang-Undang No.18 Tahun 2009, Pasal 66-67 Tentang Kesejahteraan Hewan

Dari segi perundang-undangan, bisa dikatakan bahwa pada prinsipnya Indonesia merupakan negara yang ramah satwa. Dalam UU No. 18/2009, kemampuan untuk merasakan sakit menjadi landasan yang memerintahkan perlakuan layak kepada satwa. Dalam Pasal 66 juga jelaslah bahwa kelima prinsip kebebasan satwa menjadi pertimbangan penting dalam usaha peternakan dan kesehatan hewan. Dan dari Pasal 67 dapat kita simpulkan bahwa masyarakat turut memiliki tanggung jawab untuk mendampingi pemerintah dalam upaya menegakkan ketentuan-ketentuan perihal kesejahteraan hewan. Partisipasi masyarakat ini tentu menjadi krusial karena saat ini penegakkan hukum di bidang kesejahteraan hewan masih sangat jauh dari memadai. 
Namun, kendala lainnya adalah masih sangat minimnya kesadaran dan kepedulian masyarakat Indonesia terhadap kesejahteraan satwa. Oleh karena itu dibutuhkan suatu gerakan yang mengedukasi tentang kepedulian kita akan mahluk hidup lain tidak hanya hewan tapi juga tumbuhan. Dan oleh karena itu dibutuhkan juga pemahaman filsafat pada manusia agar setiap manusia bisa berpikir dengan baik dan melakukan hal-hal yang baik juga karena kita hidup di alam semesta ini itu tidak sendiri kita juga harus memikirkan kelangsungan hidup mahluk hidup lainnya. 


\section{Daftar Pustaka \& Referensi}

Dewantara, A. (2019). Diktat Kuliah Filsafat Manusia.

Raja, Unies Ananda (2018, 25 Januari). Sejarah Singkat Diskursus mengenai Hewan dalam Filsafat Barat. Diakses pada 30 November 2019, dari http://www.balairungpress.com/2018/01/sejarah-singkat-diskursusmengenai-hewan-dalam-filsafat-barat/

Peraturan hukum yang mengatur perihal kesejahteraan satwa di Indonesia. Diakses pada 30 November 2019, dari https://www.isaw.or.id/sample-page/regulations-concerning-animalwelfare-in-indonesia/?lang=id 